\title{
Founder Expertise, Strategic Choices, Formation, and Survival of High-Tech SMEs in China: A Resource- Substitution Approach
}

by Li Xiao and Mark Ramsden

This paper uses a resource-based perspective to better understand how the three most established expertise possessed by founding entrepreneurs influence the development path of firms operating in the high-tech industrial sector. The longitudinal evidence from two rounds of face-to-face interviews with the owners of Chinese high-tech SMEs in 2004 and 2009 identifies three business strategic choices innovation, product, and production that are essential to optimize the expertise and sources of finance available for creating and growing a high-tech business. The findings from the interview evidence offer novel insights into the entrepreneurial development path of firms associated with types of entrepreneurs and availability of financial sources possessed by founding entrepreneurs.

\section{Introduction}

The importance of the founding entrepreneurs' human capital and availability of external sources of finance in determining the level of performance and the growth rate in high-tech firms is acknowledged by the growing body of literature (Colombo and Grilli 2010; Davidsson and Honig 2003; Gimmon and Levie 2010; Liu et al. 2010; Sambasivan, Abdul, and Yusop 2009; Shrader and Siegel 2007; Unger et al. 2011; Vanaelst et al. 2006; Wright et al. 2007). Yet much of this research, particularly in the context of growth and performance in young high-tech SMEs, has neglected the issue of resource substitution and how human capital substitutes finance capital, and the entrepreneurial choices emerging from the expertise and planned amount of initial investment capital held by entrepreneurs (Birley and Norburn 1987). It remains unclear how the relationships between planned amount of initial capital and types of expertise and knowledge lead to strategic choices and development paths along which founding entrepreneurs can make best use of their talents, strengths, and resources available as well as overcome resource constraints to start and grow a high-tech business.

This study uses a resource-substituted approach to examine how entrepreneurs purposively select a set of entrepreneurial choices and the interactions to start and grow a firm. We are particularly interested in how the types of expertise are best used and act uniquely as a substitute for resources that are not available internally (Clarysse, Bruneel, and Wright 2011). We argue that entrepreneurs are likely to cope with critical resources including scientific knowledge, technological knowledge, entrepreneurial skills, and finance that are not available internally by resource substitution. This

Li Xiao is at the University of Exeter and the Department of Entrepreneurship Innovation and Strategy at the Lancaster University Management School, Lancaster University.

Mark Ramsden is at the School of Sociology at Kingston University and the Department of Sociology, University of Cambridge.

Address correspondence to: Li Xiao, Management School, Lancaster University, Lancaster, England, LA1 4YX. E-mail: 1.xiao@lancaster.ac.uk. 
resource-substituted approach is particularly useful to young high-tech firms in emerging economies such as China where institutional transition has led to firms and investors being reluctant to finance long-term investments. However, it remains unexplored how a set of strategic choices emerge from the types of expertise and investment capital possessed by founding entrepreneurs. This paper adopts resource substitution theory and focuses on how each of the three established areas of expertise lead to entrepreneurs operating a high-tech business.

The entrepreneurship literature has improved our understanding of the relationship between type of expertise and selected entrepreneurial strategy from a narrow perspective as well as its relationship with the performance of firms. Such studies typically focus on one of the entrepreneurial strategies and its relation with performance of firms, but fail to examine how the expertise of founders as a key resource possessed by the firm substitutes scarce resources (Westhead and Wright 1998). A key determinant to start and grow a high-tech business may be a set of strategic choices best reflecting the strengths of founding entrepreneurs and dealing with critical resources that are not available internally. The planned amount of initial capital required to create a high-tech SMEs is influenced by the specific expertise of the founders and has proved essential in shaping the ways a firm operates. A set of entrepreneurial choices that a firm employs may vary over the entrepreneurial process, as additional knowledge and resources are developed and/or brought in by offering business partnership within the process (Knockaert and Ucbasaran 2013). This paper therefore aims to investigate how expertise and finance can be substituted for one another by founding entrepreneurs and how the mix between expertise and finance can influence the survival and growth of firms. The study examines the process by looking into choices that emerge during the early stages of the entrepreneurial process.

In this study, we focus on the three essential and interrelated entrepreneurial strategic choices namely innovation, product, and production because these choices are likely to interact to compensate for scarce internal resources. Moreover, these three aspects reflect fundamental alternatives for entrepreneurs with different work experience to find ways of maximising the use of resources (i.e., human capital, entrepre- neurial, and financial) that are available internally and overcome resource constraints. This work also investigates the continuing development of additional knowledge and skills of the founding entrepreneurs as well as the accumulated resources at the subsequent stages of business development, and how these lead to entrepreneurial choices in growing a high-tech business.

To gain a better understanding of how the three most established types of expertise (entrepreneurial, technical, and scientific) substitute for finance, we focus on three typical types of founding entrepreneur categories:

(1) Technology entrepreneurs: founding entrepreneurs with technological expertise and industrial related experience. This refers to those who developed both technological knowledge and practical business skills through previous experience of working as a technological expert on the product development in a profit-oriented organization rather than research-based projects.

(2) Habitual entrepreneurs: founding entrepreneurs with entrepreneurial experience. This refers to those who obtained a degree in either science and engineering disciplines or other disciplines, developed practical business skills through previous experience of working as a senior manager of a non-technical division in a commercial company or through prior business ownership.

(3) Science entrepreneurs: founding entrepreneurs with scientific knowledge. This refers to those who were either scientists, including overseas returnees, who worked previously on research-based projects (that may require a long lead time to commercialize the projects) in a research institute or university, or fresh graduates who have obtained a degree in science and engineering disciplines.

This study contributes to resource-based theory and entrepreneurial literature on human capital and strategic choices in several aspects. We provide insight into how founding entrepreneurs with different types of expertise choose different ways to start and grow a firm. This study specifically investigates how particular aspects of entrepreneurial choices, namely finance, innovation, product, and production, interact. It contributes to our understanding of how entrepreneurs with different skills and resources 


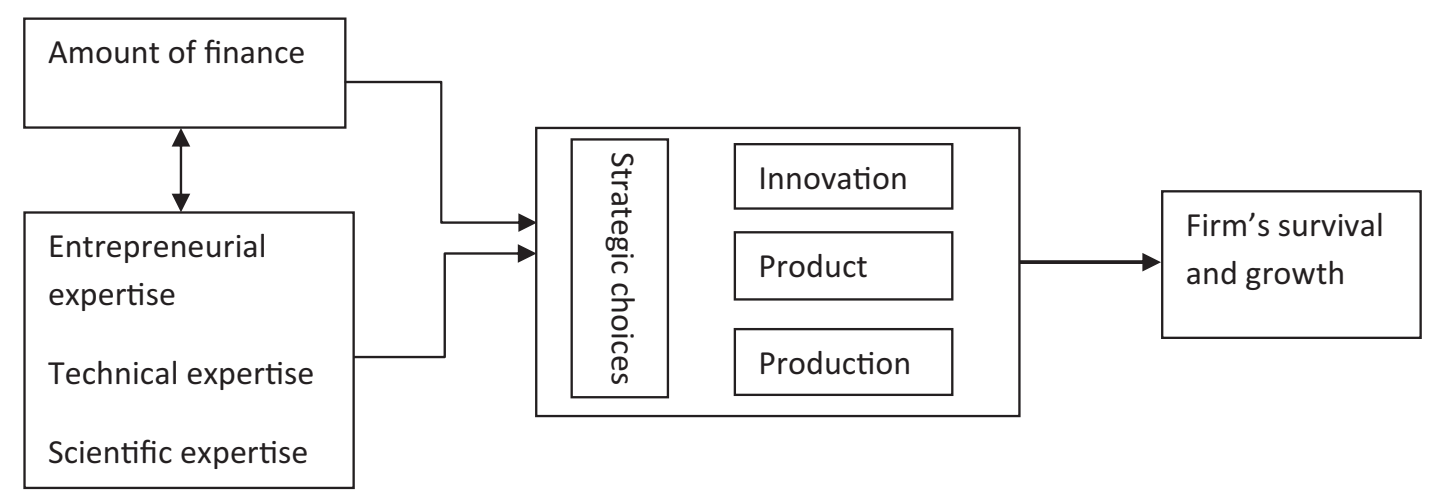

operate a high-tech business differently, helping to understand how a firm grows and why differences in growth paths exist between types of entrepreneur. We specifically investigate how sources of finance and expertise possessed by founding entrepreneurs are directed toward the planned amounts of investment capital, types of innovation (i.e., in-house versus external collaboration or technology acquisition), types of product (i.e., differentiated versus standardized), and production methods (i.e., in-house versus outsourcing) over time. This work extends human capital theory by investigating how differences in knowledge-related characteristics of founding entrepreneurs influence the chosen start-up and subsequent entrepreneurial choices. The second contribution of this paper is to capture the nuanced changes in the development path during a 10-year period by using longitudinal data combined with a rich set of qualitative evidence gained from face to face interviews with surviving and non-surviving firms (Hanks et al. 1993). We also develop a broader understanding of the dynamic interplay of human capital resources, financial resources, and entrepreneurial choices, and their effects on the business development path.

The rest of the paper is organized as follows. Initially the types of expertise and entrepreneurial choices are examined before describing the research design and methods. The empirical results are then presented and analysed contrasting the start-up and subsequent stages of business development prior to discussing the findings and their implications.

\section{Theory and Previous Research Evidence \\ Resource Substitution}

Resource-based theory and human capital theory suggest that the human capital of entrepreneurs is a key resource possessed by young high-tech firms that rely heavily on the internal resources available to them. Human capital can be used as a substitute for financial capital, enabling entrepreneurs to compensate for a deficiency in human capital resources available internally (i.e., minimize amounts of initial capital required) particularly at the early stage of business development (Chandler and Hanks 1993). Studies focusing on young high-tech firms have identified entrepreneurial expertise, technical expertise, and scientific expertise that, as shown in Figure 1, are seen to be particularly important for a firm to overcome businessrelated and technology-related issues confronted in its early years (Gimmon and Levie 2010). These studies generally agree that access to external finance is another key driver of the success of new high-tech SMEs (Colombo and Grilli 2010). We argue that resource substitution makes it possible to create and grow a new high-tech business, without a large amount of initial capital required or a specific expertise available internally, through a set of business 
strategies that are employed to run the business. However, the ability of a firm to compensate for a deficiency in finance or expertise varies according to the type of resources possessed by the founders, suggesting that different types of entrepreneurs would likely engage in a new business creation rather differently. Entrepreneurial choices that relate to the human capital characteristics of founders and availability of sources of finance play an important role in substituting scarce internal resources and the survival of a new high-tech business.

Strategic choices emerging from the resources available internally are driven by the ability of entrepreneurs to substitute expertise for investment capital (Rhoads, Townsend, and Busenitz 2011; Wernerfelt 1984). This substitution creates an unique advantage in the entrepreneurial process in the context of technology-based small firms. Human capital resources of entrepreneurs, based on prior work experience, provide a key underpinning of strategic choices and a firm's formation and survival (Westhead, Wright, and Ucbasaran 2001). An appropriate set of strategic choices allows a young firm that is typically resource-constrained to engage in business activities in a more efficient way in which the types of knowledge and skills possessed by founding entrepreneurs substitute for other resources not available internally to develop core competency (Clarysse, Bruneel, and Wright 2011; Cooper and Bruno 1997; Cooper, Gimeno-Gascon, and Woo 1994; Messersmith and Wales 2013; Storey and Tether 1998; Thwaites and Wynarczyk 1996).

More specifically, a combination of technological expertise and industrial-related experience make it possible to offer differential products that successfully fit individual customer needs and do not seem to require a large amount of initial capital to create the business (i.e., charging deposits). In contrast, scientific expertise held by science entrepreneurs is likely to result in patents that may not be readily developed into products (Wright et al. 2008), leading to a strategic intention of developing standardized and distinctive products based on the patented inventions. Seeking both sufficient amounts of capital and entrepreneurial expertise from external resources to commercialize patented inventions tend to be significant for firms founded by science entrepreneurs. Firms founded by habitual entrepreneurs are likely to develop competitive advantages by business opportunity identification and good business operation. However, a lack of technological knowledge could be substituted by sufficient amounts of initial capital in purchasing patents and recruiting employees with technological expertise. The question raised here is whether such resource substitution works for all types of entrepreneurs throughout the entrepreneurial process.

\section{Previous Research Evidence on the Relations Between Human Capital, Financial Capital, and Firm Growth}

Both formal education and practical learning experience that take place on the job (Davidsson and Honig 2003; Simsek and Heavey 2011) contributes to developing scientific knowledge, technological expertise, and practical business skills that would be particularly important resources in the context of technology-based small firms where competitiveness comes from offering the latest products to markets. Higher levels of education that provide scientific knowledge and skills have been identified as important in pioneering business opportunities and creating new high-tech firms (Bates 1990; Honig 1998). Arenius and De Clercq (2005) report a positive relationship between education levels and the likelihood of recognizing business opportunities. Although science entrepreneurs typically have PhDs (Mosey and Wright 2007), the fact that the majority of Chinese high-tech SMEs have employed existing technologies rather than developing new technologies as the source of competitive advantage negates PhDs' potential advantage. Thus, PhDs do not necessarily create a competitive advantage compared to Masters or First degrees in a technological field in terms of developing new products in the established technology. Instead those subject disciplines that help develop advanced expertise and skills in entrepreneurial activities are considered in this study to be more influential on the ability of firms to employ specific business strategies and a firm's survival and growth.

Gimmon and Levie (2010) have found that, based on a random sample of 193 high-tech start-ups in Israel, a founder's business management expertise and academic status attracted external investment. However, a significant proportion of entrepreneurs who have great experience and would like to retain the innovative nature and control of the business have more conservative attitudes toward raising and using both external loans and equity finance, and may therefore plan to invest a small amount of initial capital to start a high-tech business (Barton and 
Matthews 1989; Cooper 1981; North and Smallbone 2000; Norton 1991). Moreover, the fear of being unable to repay loans in the event of financial distress combined with a preference for spreading financial risks also prevents many founding entrepreneurs from planning sufficient amounts of initial capital and seeking external finance (Xiao 2011). It remains unclear how poorly funded high-tech firms start and operate their business and make it successful (Audretsch and Keilbach 2004; Barney 1991, 2001; Cressy 2006; Westhead, Wright, and Ucbasaran 2001). The human capital resource of entrepreneurs is predicted to enable firms to grow faster and at lower cost through selecting a set of strategic choices during the early stage of business development (Cressy 2006; De Clercq and Arenius 2006; Storey and Tether 1998; Thwaites and Wynarczyk 1996). Such behavior is likely to be more prevalent in emerging economies where environmental and competitive uncertainty is higher (Vaessen and Keeble 1995; Xiao and Ritchie 2009). The optimal course of action is contingent (dependent) on the internal and external situation. This study is to investigate how a lack of enthusiasm for investing sufficient amounts of capital enables a firm to compete with its well-funded competitors in the market by looking into strategic choices and the types of expertise.

Studies highlight the role human capital plays as a driving force behind the growth and performance of high-tech firms (Chandler and Jansen 1992; Shane and Khurana 2003; Teece 1986). Cooper (1993) reported that the single most important influence on the ability of an individual to identify and recognize new business opportunities was work experience. Drawing on a business survey of start-up firms, Davidsson and Honig (2003) found that firsttime entrepreneurs with work experience were more likely to discover and recognize business opportunities. Wright et al. (2008) outlined that a combination of technological knowledge and entrepreneurial experience was the single most important influence on the growth and performance of high-tech SMEs. Shrader and Siegel (2007) reported that on a longitudinal analysis of 198 technology-based new ventures the fit between strategy and entrepreneurial experience was significantly related to, and represented a key determinant of, the financial performance of firms. These findings demonstrate the importance for technology-based new firms to select entrepreneurial choices for which they possess execution expertise. The possession of human capital is considered to enhance competitive advantage and consequently increase the return on firm strategies (Hitt et al. 2006; Sandberg and Hofer 1987; Simsek and Heavey 2011; Tan 2002). Selecting an appropriate set of entrepreneurial choices enables firms not only to maximize the utilization of its particular knowledge and skills but minimize the effects of resource constraints on business survival and growth over time (Simsek and Heavey 2011).

The relationship between the personal attributes of entrepreneurs and the growth performance of their firms (Gartner 1988; Shrader and Siegel 2007; Ucbasaran et al. 2003) is inconclusive in terms of the entrepreneurial characteristics required consistently to influence firm performance (Unger et al. 2011). Scientific knowledge, technological expertise, and practical business skills have recently become established components of human capital resources in studies focusing on the effects of founders' human capital on performance of high-tech firms (Gimmon and Levie 2010; Shrader and Siegel 2007; Wright et al. 2008). Previous studies have found strong links between the type of work experience of entrepreneurs and entrepreneurial orientations (Honig 1998; Wright et al. 2008). Prior work experience in business practices and technology knowledge were found to be equally important in identifying and recognising new and innovative business opportunities (Gimmon and Levie 2010). However, it remains unclear as to how prior specific experience of founding entrepreneurs leads to the particular ways of running a high-tech firm to ensure a business is a relatively long-term success (Xiao, Larson, and North 2013).

\section{Human Capital, Financial Capital, and Strategic Choices}

As noted earlier, technological entrepreneurship literature has acknowledged the three established types of expertise that are particularly important to attract external finance and/or enhance a firm's survival and growth. However, we know little about why the majority of young high-tech firms that survive and succeed have not sought and accepted external investment, and how these firms were able to minimize the amount of initial capital required to start the business. How does the ability of a firm to start a high-tech business at low cost vary according to the type of expertise possessed by founding 
entrepreneurs? It remains largely unexplored how the type of expertise possessed by entrepreneurs influences the ability of a firm to minimize the amount of initial capital required. We therefore pose the following research question (RQs):

RQ1: What types of expertise possessed by entrepreneurs are best able to substitute for the amount of finance required to start a high-tech business?

For a start-up firm to create competitive advantage, the strategic choices emerging from the availability of resources are likely to include innovation, product, and production methods as mechanisms for leveraging the specific expertise possessed by founders and from planned capital investment. Specifically, the literature on entrepreneurship suggests that innovation is the key for SMEs to compete against both well-established companies as well as small counterparts in the market (Wright, Robbie, and Ennew 1997). Schumpeter (1934) highlighted the importance of individual entrepreneurs to innovation and placed an emphasis on matching innovation with the availability of resources. Rosenbusch, Brinckmann, and Bausch (2011) found that, based on 42 empirical studies on 21,270 , internal innovation projects, innovation had more positive effects on the performance of young firms than did external collaboration. Research on technological entrepreneurship suggests that new firms that focus on meeting customers' needs enjoyed better financial performance than those that put more effort into developing patented inventions, particularly at the early stage of business development (Xiao, Larson, and North 2013). An innovation strategy is defined as a choice between full engagement with internal innovation projects and reliance on external research partners for distinctive product development. It seems that the interaction between planned initial capital outlay and type of expertise leads to an emergence of innovation choice. This reflects that founding entrepreneurs who minimize the amount of initial capital outlay are prepared to forgo a high salary before generating sales turnover and profits. Therefore:

RQ2: What innovation strategies are utilized by entrepreneurs with different types of expertise and different access to finance to operate a high-tech business at the early stage of its development?

The choice of offering either differentiated or standardized products/services to the market
(Porter 1985) is considered as a strategic option. This is influenced by the human and financial capital resources of founding entrepreneurs. Differentiation is defined as a business strategy to develop purposefully a unique product to meet the specific needs of a particular customer or group of customers. In contrast, standardization is defined as a choice to sell products that achieve a broader position, broader than a niche position, within a market. In this study, a standards-related item is likely to form a part of the final product. A young high-tech firm be would likely to create competitive advantages by making the best possible fit between its chosen product strategy and its capability to deliver the targeted products (Barczak 1995). The possession of human capital resources and start-up capital may be one of the important factors influencing the selection of a product strategy, which may change over time. Although both technological and scientific entrepreneurs have great expertise in new product development, their understanding of the specific requirements of individual customers may differ. The selection of product strategy is also associated with the time taken and amount of investment necessary for the development of a distinctive product. The larger the amount of resource that is required, the more likely they are to pursue a standardized product strategy. Therefore:

RQ3: What product strategies are utilized by entrepreneurs, with different types of expertise and access to different quantities of finance, to create and operate a high-tech business at the early stage of its development?

The amount of resources required to produce products can also be leveraged by the chosen production strategy. This is referred to in this study as a choice between outsourcing of production and producing in house, directing toward amounts of actual investment capital in production equipment. Outsourcing production is defined in this study as the contracting out to external suppliers of some, or all, of the product production process to reduce the amount of investment capital in particular associated with the purchase of production equipment. Outsourcing enables a firm to focus more on the core business (Neck et al. 2004). In addition, outsourcing production allows a firm to reduce the level of the risk associated with fluctuating product demand and increases the efficiency of investment capital. The selection of production strategy varies according to resources available internally and the ability of entrepreneurs to 
manage the level of risk involved. Entrepreneurs with technological expertise may be more comfortable with managing technology-related risks. In contrast, those with entrepreneurial expertise may be more comfortable coping with the risks emerging from production and market related issues. Therefore,

RQ4: What production strategies are utilized by entrepreneurs with different types of expertise and access to different quantities of finance to operate a high-tech business at start-up and early development stage?

\section{Research Design and Metbods}

The central issue that this research concerns is how founding entrepreneurs with different expertise and varying access to finance leverage strategic choices and resources available for starting and growing a high-tech business. A longitudinal study comprising two rounds of face-to-face interviews with entrepreneurs of high-tech firms covering sequential time periods is employed to investigate this research issue. These longitudinal data enable us to study the development path of a firm over a ten-year period during which emerging privately owned high-tech SMEs were seen to have developed dramatically in China. The two rounds of faceto-face interviews were conducted in 2004 and in 2009 again. The first round covered the period from 1998 to 2004 and the second focused on the period between 2004 and 2009 . The results of the longitudinal study of technological entrepreneurial development were based on a total of 100 face-to-face interviews with the owner/senior managers of high-tech SMEs comprising 50 firms that were successfully interviewed on two occasions in 2004 and again in 2009. These two rounds of interviews with the owner/senior managers were guided by a semistructured questionnaire by which qualitative information was collected on the strategic choices and business development paths.

The aim of our interviews with entrepreneurs of high-tech SMEs was to understand as much as possible about how their strategic choices and business development paths correspond to type of expertise and availability of finance. The interviews explore what, and why, specific entrepreneurial strategies had emerged and selected to start and grow a high-tech business. The two rounds that were conducted allowed us to observe not only the more explicit strategies but also the more implicit or "nuanced" changes in the running of a high-tech business over the stages in a firm's development. Empirical evidence from the two rounds also made it possible to explore the research question of as to how the specific types of knowledge and skills possessed by entrepreneurs were employed in sustaining a high-tech business. Evidence from the face-toface interviews with entrepreneurs of high-tech SMEs allows an evaluation of the additional human capital and associated resources acquired as a result of managing a high-tech business between the two rounds of interviews. Related assessments may be made on the selection of entrepreneurial alternatives and performance.

Face-to-face interviews with the entrepreneur/senior managers of high-tech SMEs were undertaken to investigate in-depth:

- How differences in the prior knowledge and skills of the founding entrepreneurs have influenced strategic choices in operating their firm at the start-up, and the implications of these strategic choice for the performance of firms.

- The effects of additional expertise accumulated/brought in during subsequent stages of business development. Information on the experience of creating and sustaining a hightech business in the market relating to finance, innovation, product and production was collected during the interviews.

Information on the role of founding entrepreneurs who have played a leading role in business success was also gathered. This has provided an important empirical basis for identifying the crucial knowledge and skills associated with entrepreneurs creating and developing young high-tech SMEs.

\section{The 2004 Interview}

The criteria by which firms were selected for the 2004 interview were: (1) firms with less than 250 employees which were independently owned, (European SME definition; (2) firms operating in the two high-tech industrial sectors namely, the electronic and information technology (EIT) and biotechnology (Bio-Tech) sectors, utilizing the China National Bureau's definition; (3) firms located in the two provinces of Guangdong and Guangxi, representing both the wealthier and peripheral regions of China. A pilot study was carried out in the two study regions in the 2004 interview. A semistructured questionnaire was modified based on the 
Figure 2

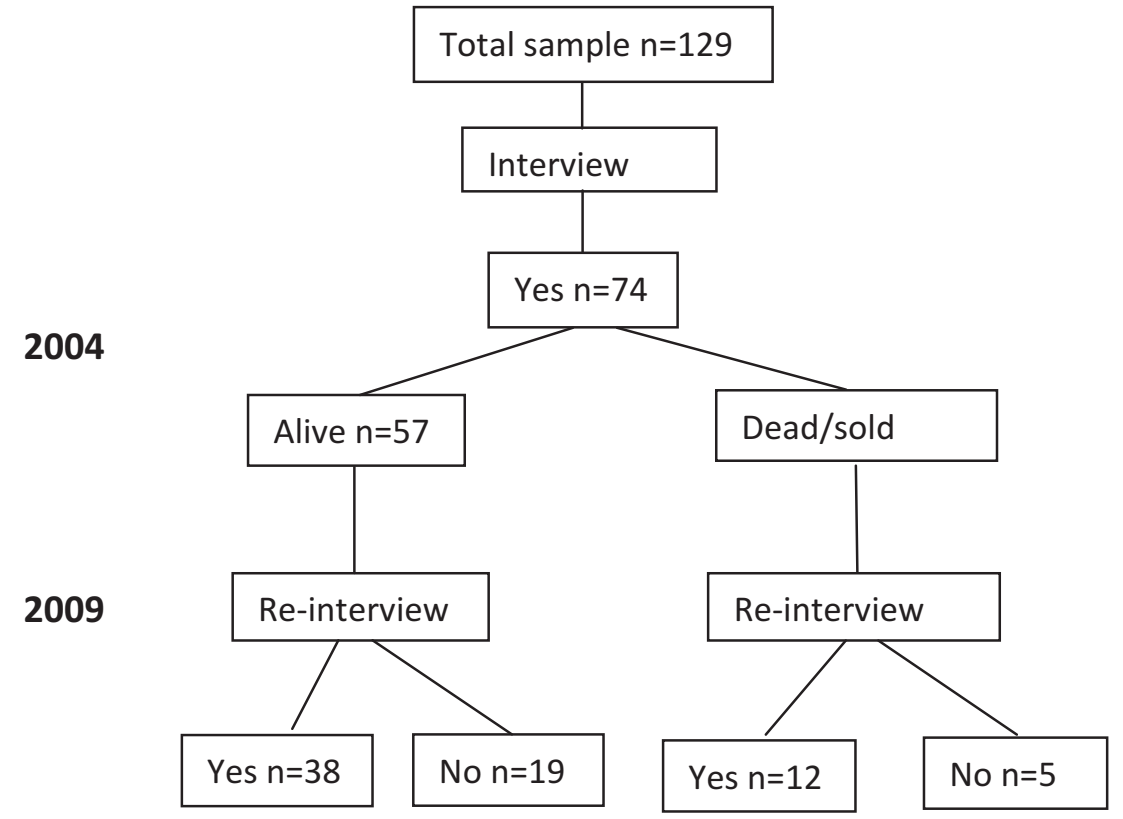

feedback received from the four face-to-face interviews. Specifically, we added a question related to the types of products (differentiated versus standardized) firms intended to launch into the market.

A sample of 129 high-tech SMEs that met the criteria was drawn from the sampling frames provided by government agencies at the national level from four high-tech parks within the two selected provinces. These firms were approached and invited to participate in the first round of face to face interviews in 2004. As shown in Figure 2, interviews were successfully conducted with 74 of these entrepreneur/senior managers in 2004, representing a response rate of 57 percent. The interviews with the respondents lasted on average one hour. In addition, and a follow-up telephone interview was conducted when additional information was required. The main reason for nonparticipation in the survey interview given by potential respondents was that they were too busy to afford time for an interview. Table 1 shows, among all the 74 firms, 50 percent of the 2004 sample (37 firms) were started by technology entrepreneurs, 31 percent of the sample (23 firms) were founded by habitual entrepreneurs, with only 19 percent of the sample (14 firms) established by science entrepreneurs. It is worth noting that expertise held by initial founders was taken into consideration, although the majority of interviewed firms added new business partners to the team soon after the establishment of firms.

\section{The 2009 Interview}

Before the 2009 interviews were conducted, the survival status of the 74 firms interviewed in 2004 were sought by telephone and online resources. In cases where the contact details of the firms had changed information on the survival status of the firm was provided by government national agencies who deal with four high-tech parks. All 74 firms including surviving and nonsurviving/sold were contacted and invited to participate in the second round of interviews to take place in 2009. Face-to-face interviews were successfully conducted with 50 of the firms (38 firms operating in the market has closed down while 12 firms either had sold up), giving a response rate of 65 percent, as shown in Figure 2. The interviews with the respondents lasted on average one hour and as in the 2004 interviews where necessary a 


\begin{tabular}{|c|c|c|c|c|c|c|c|}
\hline & \multirow[t]{2}{*}{ Total } & \multicolumn{2}{|c|}{ Technology } & \multicolumn{2}{|c|}{ Habitual } & \multicolumn{2}{|c|}{ Science } \\
\hline & & No. & Percent & No. & Percent & No. & Percent \\
\hline 2004 & 74 & 37 & 50 & 23 & 31 & 14 & 19 \\
\hline 2009 & 50 & 27 & 54 & 13 & 26 & 10 & 20 \\
\hline
\end{tabular}

Note: the research findings were based on the information collected from 50 firms that were interviewed on two occasions in 2004 and again in 2009.

follow-up telephone interview was conducted when additional information was required. Information on the sources of finance utilized, the amounts of capital invested in fixed assets, experience of growing a business focusing on new product development, methods of production, and the causes of business failure were collected. The main reason for non-participation in the second survey given by respondents was that they were either too busy or not interested in the second interview. The performance effects of the different types of expertise and the chosen entrepreneurial strategies are discussed in the results section later in the paper.

\section{The Findings from the Longitudinal Study}

\section{Human Capital, Financial Capital, and Strategic Choices}

Chandler and Hanks (1998) reported that human capital, primarily measured by the level of education, enables entrepreneurs to compensate for financial capital that is not available internally, and the resource-substitution is positively associated with the growth and performance of firms. In the high-tech industrial sector, the majority of entrepreneurs have high levels of education and qualifications such as a Masters or PhD (Mosey and Wright 2007; Xiao Larson, and North 2013), thus academic education does not necessarily create a unique competitive advantage. Instead, the three most established areas of expertise including technological, scientific, and entrepreneurial may be the key for strategic choices and financial alternatives employed by a firm. From our interview evidence, we find that the amount of initial capital invested to start a high-tech business varies according to the type of entrepreneur through the strategic choices and development paths employed. Founding entrepreneurs with industry-related experience and technological knowledge are in a better position to start a business with only a small amount of initial capital (a small amount is referred to the firm investments less than RMB 1 million Yuan $[£ 66,667 ; 2004])$. This is evident from statements made from several technology entrepreneurs of firms across all the cities studied: "we invested only a few ten thousand Yuan to start our business by providing the product to meet the specific requirements of our initial customers who had actively initially contacted us and asked for technological support when we worked at a research institute/university." Surprisingly, a motive for habitual entrepreneurs to invest in a high-tech business is to be qualified as a firm that is eligible to purchase a piece of land from a high-tech park. Such return on investment in real estate properties by the registration of a high-tech firm is considered to be significant. Several habitual entrepreneurs claimed that "we initially invested several million Yuan of our savings or profits from other business to create a high-tech business (e.g., mainly in purchasing the land use rights to build plant)." These cases reflect that specific type of expertise influences how business opportunities are perceived by entrepreneurs and has resulted in the adoption of a specific financial strategy to capture business opportunities.

Strategic financial choices have changed over the entrepreneurial process as successful entrepreneurs have accumulated sources of finance that can be re-invested in the firm and additional expertise is developed. This is illustrated by a statement made by an interviewee that is typical of the views articulated by several technology entrepreneurs from the 2009 interviews, claiming that "we have recently invested ten million Yuan 
including the profits, retained earnings, and funds raised from our senior staff members to purchase the land use rights to build a new plant with improved production equipment." When asked the reason for investing in the purchase of a piece of land to build a plant rather than investing in R\&D and innovation, the entrepreneurs responded that a significant increase in the value of real estate properties encourages steady growth firms associated with technology entrepreneurs to re-invest retained earnings in purchasing the land use right to build a new plant. Conversely, well-funded firms of habitual entrepreneurs are prepared to move on to any business where the profit margin is high. A habitual entrepreneur of a firm in Zhuhai stated that " my firm is yet to launch the target product over a period of four years. I sold the firm in 2007 because of the uncertainty of the lead time taken and extra cost required." Another habitual entrepreneur claimed that "my firm was financially successful in the first several years and then went into difficulty over the last few years. As a result, no further sufficient capital was invested in the business." These cases suggest that the development path associated with financial strategies varies depending on the specific expertise possessed by the main entrepreneurs. It has been difficult for firms of habitual entrepreneurs to continue investing in a business without generating sales turnover over a relatively long period of time. It has been better for these firms to sell the business at right time, as discussed in the following sections. Discovering new business opportunities and moving on rather than keeping on investing in R\&D and innovation has become a strategic choice for habitual entrepreneurs.

To examine the relationship between expertise and financial choice, a parsimonious econometric model is employed. Model 1 in Table 2, considers financial investment at start-up, and shows that habitual entrepreneurs are 59 percent more likely to establish a well-funded firm (the firm investments more than RMB 1 million Yuan $[£ 66,667 ; 2004])$ than either technology or science entrepreneurs. However, this finding does not hold at the subsequent stages (Model 2) when technology entrepreneurs are the most likely to invest larger amounts of capital into their businesses. Thus, it would appear that financial choices vary over time depending on the changes in human capital and financial capital available.
In the next section, we present the three strategic choices available to firms of entrepreneurs holding different types of expertise and how these expertise influence the development path of firms, interacting with the availability of sources of finance.

Innovation Strategic Choice. An innovation strategic choice between innovation in house and external collaboration and technology acquisitions for young high-tech firms emerges from the types of expertise (Dyer, Gregersen, and Christensen 2008; Shrader and Siegel 2007; Simsek and Heavey 2011). However, the links between the types of entrepreneurs and innovation approaches in the start up of high-tech business remain unexplored as does how their links change over the entrepreneurial process (Liefner, Hennemann, and Xin 2006). We find that technological and scientific entrepreneurs are more likely to conduct/lead internal R\&D and innovation, whereas habitual entrepreneurs tend to opt for external collaboration/technology acquisitions (Veugelers and Cassiman 1999). Although both technological and scientific entrepreneurs are involved in R\&D and innovation, the distinction between them is that the former are more likely to apply existing advanced technologies to develop differentiated products for individual customer needs. In contrast scientific entrepreneurs are more likely to develop new technologies and gain patents that take longer to be developed into products. Nevertheless, firms of technology and science entrepreneurs are more capable of succeeding in business in fastchanging, high-technology industrial sectors because they continue to discover and explore new related business opportunities. Those founded by habitual entrepreneurs are in a better position to recognize emerging business opportunities and apply an exit strategy for recouping the capital they invested in the firm when this is necessary.

Technology and science entrepreneurs in our study during both the 2004 and 2009 interviews consistently made comments as exemplified by the following quote: "As the owner of a bightech business, we have to play a major role in developing and launching the latest version of products to the market constantly." A technology entrepreneur of an EIT in Guilin stated: "senior members of staff who work as technology expertise could not spot new relevant business opportunities. I am responsible for that." A number of technology and science entrepreneurs 


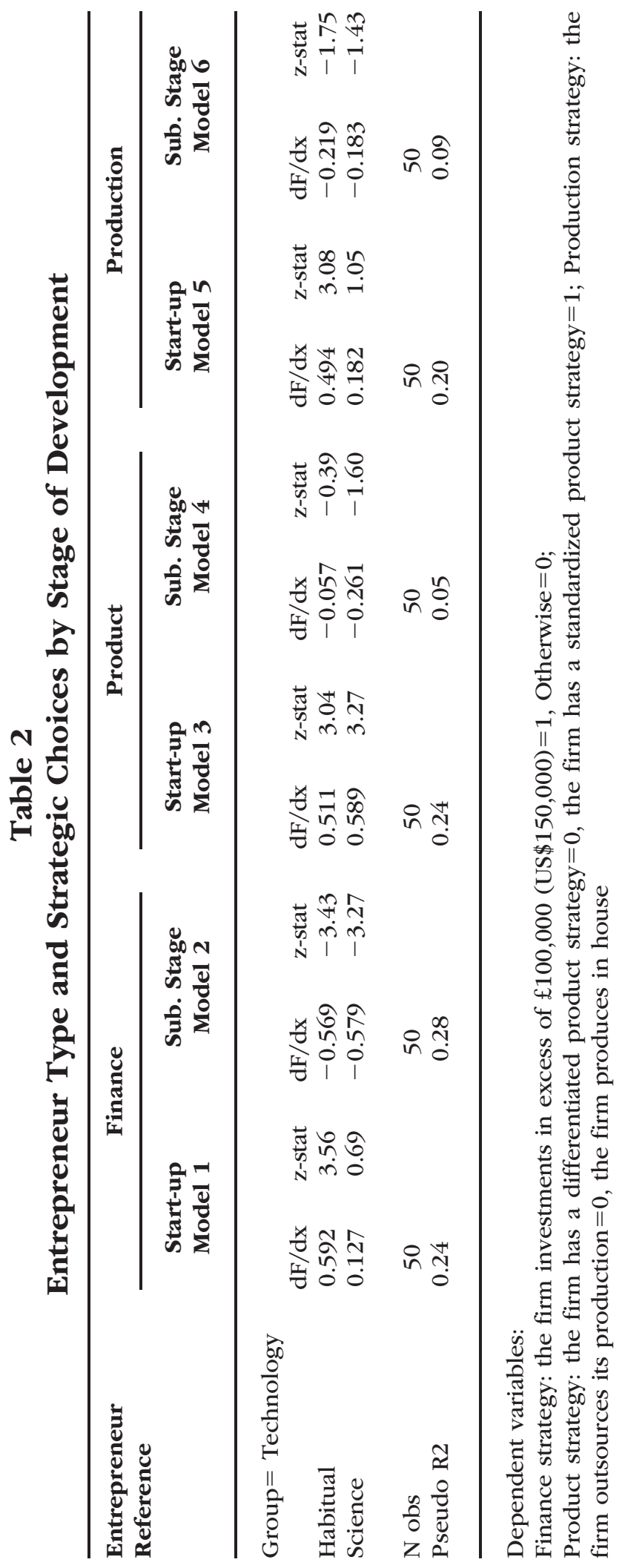


suggested that "in order for firms to remain competitive in the market, we have to work on the latest version of the products before profit margins on our existing single/group product/s declined sharply." These comments suggest the importance of developing a new, or the latest version of a product, for the survival and growth their firms run by entrepreneurs who are keen on involving themselves in R\&D and innovation. Technology and science entrepreneurs' ability to engage with R\&D and innovation to develop distinctive products has been proven to be an essential key ingredient for a firm's long-term business success.

From our evidence among firms initiated by habitual entrepreneurs, innovative strategic choice emerges as an important factor when external collaboration/technology acquisitions have changed over the entrepreneurial process. This is illustrated by statements made by a habitual entrepreneur of an EIT firm in Zhuhai from a 2004 interview: " $m y$ research partner, a well-known professor with his team from the University of Lanzhou (North West China) has been conducting RED to develop equipment for cancer treatments that were expected to overcome the problems the existing products have in the market." In the 2009 interview, he noted that "the products were still yet to launch. I therefore sold the business at a reasonable rate and moved back to the rail transport business." In 2004 another habitual entrepreneur of a biotech firm in Guilin, noted that "buying a patent from a university/research institute and working with inventors is an appropriate way to move into a high-tech business. Concentration on marketing worked well for my firm." However, in the follow-up interview in 2009 he said: "I have sold the business to people who possess technology knowledge and experience of developing relevant products." These quotes relating to different stages in a firm's development show that a well-funded firm at start-up stage with a strong production capacity can gain advantages at a later stage by selling the firm to new entrepreneurs who possess both technological and entrepreneurial expertise. A lack of technological knowledge has led habitual entrepreneurs to be innovative in seeking new business opportunities rather than looking for new product development. This is illustrated by statements from several habitual entrepreneurs that "we survey tentatively any possible business opportunity before profit margins on the single/ groups of product/s decreased." It is evident that habitual entrepreneurs are less interested in continuing to offer the latest version of products than in making a move on other businesses. Technological and science entrepreneurs are keen on creating competitive advantages by conducting innovation in house for new product development whilst habitual entrepreneurs are interested in outsourcing $R \& D$ and innovation and concentrating on market-related issues. Our evidence suggests that firms that outsourced R\&D and innovation are less able to sustain a high-tech business. This suggests that human capital characteristics influence firm's innovative focus and its development path. However, we admit that it seems not possible to construct a viable model for innovation choices because of a lack of variation in this variable between three types of entrepreneurs.

Product Strategic Choice. We have found that product strategic choices (i.e., differentiated or standardized products/services) utilized by startup firms vary, once again, depending on the types of entrepreneurs. However, the differences in product strategic choices between entrepreneurs become less pronounced with business growth and development. The selection of product strategies allows a firm to leverage expertise and resources available internally or gain credibility to secure access to external resources. Differentiated products/services are likely to be offered by start-ups founded by technological entrepreneurs because they have a good understanding of the specific needs of individual customers and a good relationship with potential customers. Offering differentiated product/services also makes it possible to start a business with a lower amount of initial capital. This is illustrated by statements made from several entrepreneurs of software firms from 2004 interviews, claiming that "we, as a programmer, developed custom software for each of our clients." One of these firms, which was a fastgrowth EIT company in Shenzhen, noted in the 2009 interview that "we now not only continue provide IT outsourcing services as before, but develop and sell toy computer programmes to both Chinese and foreign toy companies." These cases reflect that the ability of a firm to offer standardized product/services has developed as the firm grows. It also helps illustrate that the integration of technological knowledge and industrial-related experience in the entrepreneurial process enables firms initiated by technological entrepreneurs to continue to spot new 
business opportunities and sustain a business within the high-tech industrial sector.

In contrast, scientific entrepreneurs prefer to offer standardized product/services to the market to generate considerable return on investments in gaining patents and to develop these distinctive products. Habitual entrepreneurs are also prepared to launch standardized products/ services to the market based on the ability to establish production capacity. The development path of firms associated with scientific entrepreneurs differs from those run by habitual entrepreneurs, indicated by product strategic choices over the entrepreneurial process. A firm manufacturing medicines associated with cancer treatment was initiated by a professor of biology from a university and his three $\mathrm{PhD}$ students, and a private investor was soon added to the start-up team. After pilot trials proved successful, a large listed company saw potential benefit in the business opportunity and provided substantial equity finance that was used to invest in manufacturing standardized products and marketing these products. In contrast, an habitual entrepreneur of an EIT firm producing printed circuit boards previously located in Shenzhen stated that "we turned our plant into commercial properties in 2006 and rented it out." Several other habitual entrepreneurs of firms stated that "we have been engaging in different business activities over the last two decades. It is important to seize any new business opportunities." These examples show that firms of technology entrepreneurs were more capable of identifying and recognizing new and relevant business opportunities at the post start-up stages of business development. It also shows that scientific entrepreneurs who are keen on conducting radical innovation look for external investors and professional business developers to join their start-up teams. Habitual entrepreneurs are well prepared to move on to other business activities where they can maximize the utilization of their resources. Models 3 and 4 in Table 2 consider start-up and the subsequent product strategic focus. At the start-up stage, habitual and science entrepreneurs are significantly more likely (51.1 percent and 58.9 percent, respectively) to offer a standardized product than technology entrepreneurs. However, at the later stage these differences disappear and all types of entrepreneurs are equally likely to offer standardized products in a situation where they have accumulated or brought in additional resources to do so.
Production Strategic Choice. Outsourcing of production has been employed by start-up firms to reduce the amount of capital required for production capacity and to reduce the level of risk involved in investment in production equipment and market-related issues. Firms of founders focusing on the latest version of products are likely to outsource the production of components used in the final product. This is illustrated by a quote representative of a number of technology entrepreneurs taken from the 2004 and 2009 interviews: "we initially outsourced production and re-assembled the parts of our final products, but we now produce more parts in-house compared to the start-up stage. We have been cautious to re-invest sufficient amounts of profits made in production equipment since a rapid change in technologies increases the level of risk for sufficient investments in expensive production equipment when operating at much less than the full capacity." The interview data indicate that the selection of production strategies varies according to the business development stage and is also influenced by additional knowledge developed through the entrepreneurial process. Entrepreneurial expertise does help manage the level of risk involved in investment in production equipment and market-related issues. Moreover, it reflects that outsourcing production enables firms to lower the risk associated with fluctuation in demand and allows a firm to concentrate on the core business.

Firms initiated by scientific entrepreneurs who are keen on new product development are likely to add business partners with sufficient funding as well as industry and market related knowledge to the entrepreneurial team. Inhouse production can be a good choice for firms wishing to reduce the level of uncertainty associated with production and have the resources to do so. However, problems that may be caused by having business partners with different mindsets (i.e., in terms of expertise and knowledge) could also lead to business failure. This was clearly explained by one of the founders, in a 2009 interview, of a firm producing Chinese input software in Zhuhai: "the main reason why the firm was closed two years after offering business partnership to three external investors in 2008 was the conflicts of interest in operating the business." Thus, external assistance makes it easier to access sources of finance and enables a firm to produce in house, 
but the downside could be the conflicts between initial founders and new business partners.

Firms initiated by habitual entrepreneurs who are interested in intermediate products differentiate from their counterparts and create competitive advantages through investing lin advanced production equipment. The following quote illustrates a common concern among several habitual entrepreneurs who invested at least one million Yuan (RMB) in production equipment either at the start-up stage or subsequent stage: "we had to make sure to generate a full return on the investments in production equipment within a few years before the profit margin per unit decreases sharply. Otherwise, the risk that we take on would be too high to make profits." This statement suggests that, in general, habitual entrepreneurs possess the ability to understand the life span of a product and interact with the market (Mosey and Wright 2007). In respect of production, Model 5 in Table 2 show that habitual entrepreneurs are 49.4 percent more likely to adopt an internal production method at the start-up, Model 6 reveals these initial differences between types of entrepreneurs vanish at subsequent stage when all types of entrepreneurs are equally likely to shift from outsourcing production to internalize production.
Having discussed the links between expertise, the financial resources held by founders and the strategic choices available to a firm, we now estimate whether particular types of entrepreneurs contribute to faster firm growth and the long-term success of a business. We use employment as a growth indicator. It is the most widely employed measure in empirical growth research as it is often the only one available (Delmar, Davidsson, and Gartner 2003; Wright et al. 2008). More importantly, the use of this measure makes it possible to reflect the differences in employment growth orientations between the types of entrepreneurs. The period of growth we consider is 10 years between 1998 and 2009. In this case the dependent variable is expressed in percentage terms by subtracting previous employment from current employment and dividing by previous employment $(\mathrm{dE}=($ Employment2009-Employment2004)/ (Employment2004)). As the employment change variable is continuous, we estimate our growth models by Ordinary Least Squares. Model 1 in Table 3, our base model, indicates that science entrepreneurs recorded the highest employment growth rate, on average 6.4 percent higher than either habitual or technology entrepreneurs. When start-up and subsequent stage strategic

\section{Table 3}

\section{The Performance Effects of Entrepreneur Type and Chosen Strategy}

Employment Growth

\begin{tabular}{cccccc}
\hline \multicolumn{2}{c}{ Model 1} & \multicolumn{2}{c}{ Model 2 } & & Model 3 \\
\cline { 5 - 6 } Coefficient & t-stat & Coefficient & t-stat & Coefficient t-stat
\end{tabular}

Type of entrepreneur:

technology $=$ reference

Habitual

$-2.35$

$-1.24$

$-1.97$

$-0.92$

Science

6.40

2.52

5.64

2.04

6.99

2.85

Strategy

Finance

Product

Production

-2.27
-1.10
4.01

-0.98
-0.60
1.63

1.37

0.85

$\begin{array}{ll}1.55 & 0.91\end{array}$

Constant

2.17

2.70

2.33

2.66

0.92

$\mathrm{N}$ obs

38

0.16
38

0.21 
choices are included, firms by science entrepreneurs outperformed those by technology and habitual entrepreneurs (see Models 2 and 3 in Table 3).

\section{Discussion}

In this study, we have investigated how the specific expertise possessed by founding entrepreneurs influence the strategic business choices of Chinese firms operating in high-tech sectors, including EIT and Bio-tech. The study is inspired by a resource-based perspective (Lu and Tao 2010). The insights gained from the qualitative interview data spanning a decade add richness and depth to our understanding of how the expertise of founding entrepreneurs and the availability of internal sources of finance influence the business development path over time (Batjargal 2007, 2010; Clarysse, Bruneel, and Wright 2011). The findings from the interview evidence offer novel theoretical insights into the entrepreneurial development path of firms associated with types of entrepreneurs and availability of financial sources possessed by founding entrepreneurs. The development path of a firm is framed by a combination of human capital characteristics and availability of financial sources, and shaped by emerging strategic business choices available to a firm. Specifically, we propose that the three business strategies of innovation, product, and production related to the availability of resources are the mechanism by which resources for a startup firm either substitute for one another or are assembled from external providers. These three specific business strategies enable a firm to leverage expertise and finance that are either available internally or accessed from external suppliers to create competitive advantages.

This study expands our understanding of how each of the three most established expertise influence the formation and growth of a high-tech business (Colombo and Grilli 2010; Gimmon and Levie 2010; Wright et al. 2007), and our understanding of how each of them acts as either a substitute for resource constraints or credibility for access to external resources. The empirical work examines the development path in which different types of entrepreneurs have operated a high-tech business over a period of ten years in China and the effects of intra-strategic choices on the survival and growth of high-tech SMEs. By focusing on the longitudinal evidence spanning a decade, this paper goes beyond previous studies showing how strategic choices emerge within firms associated with different types of founding entrepreneurs, and change over time corresponding to additional expertise developed and internal sources of finance accumulated.

Our strategic choice approach has helped specify that a combination of technological expertise and industrial-related work experience held by technology entrepreneurs is best able to substitute for the sources of finance required to start a new business. This resource-substitution occurs via a set of strategic choices including applying existing technologies to develop product/service, offering product differentiation, and the outsourcing of production. By so doing, the amount of initial investment capital required for technology entrepreneurs to start a high-tech business is minimized. Once established, these healthy start-up firms then re-invest retained earnings and profits generated in subsequent business activities but now facing a different set of strategic choices (i.e., R\&D and innovation for distinctive standardized products and/or building a new plant for production in house) reflecting the specific resources and knowledge accumulated over the life of the firm.

Firms initiated by scientific entrepreneurs are likely to look for industry-related knowledge and sources of finance from external providers by offering business partnerships where patents granted and standardized products/services are attractive to external factors (Rasmussen, Mosey, and Wright 2011). It appears that scientific knowledge possessed by scientific entrepreneurs barely substitutes for both industryrelated knowledge and funding sources given that a firm prefers to make use of internal resources rather than external resources (such as recruiting business partners).

The entrepreneurial expertise possessed by habitual entrepreneurs with sufficient amounts of investment capital have the option to seek technological knowledge from external providers by purchasing patents from a research institute/university rather than recruit new business partners with scientific knowledge. Contacts with academic scientists who developed the technologies and/or products enable habitual entrepreneurs to better understand the technologies and be more confident of purchasing the patents, a finding consistent with research focusing on the role of networks in entrepreneurship (Jack 2005; Zhang et al. 2008). The main reason why habitual entrepreneurs do not 
offer business partnerships to academic scientists may be that both parties avoid potential conflict and complexity between entrepreneurial team members. Sources of internal finance are used to compensate for a lack of scientific knowledge and for developing new standardized products/services. The competitive strength of these firms lies initially in their production capacities and market-related knowledge, and developing an exit strategy to sell the business and move on to other business activities at an appropriate moment.

This study therefore provides a better understanding of how a firm either compensates for financial constraints or gains access to external funding, and how these behaviors play a role in the start up of a high-tech business and its development path. Technology and habitual entrepreneurs who have a wide range of resources that can substitute for scarce resources to address a high-tech business opportunity are reluctant to add new business partners to the entrepreneurial team to obtain external resources. The distinctiveness between technology and habitual entrepreneurs is that firms founded by habitual entrepreneurs are more likely to use internal resources available and generate a significant return on their investments in projects (i.e., mainly in real estate properties) rather than generating business success over a relatively long period of time. Resource substitution has been an important means to start a high-tech business among firms initiated by both technology and habitual entrepreneurs.

Most studies of young high-tech SMEs have established the importance of technological expertise and the practical business skills of founding entrepreneurs. (Colombo et al. 2009; Gimmon and Levie 2010; Westhead 1995; Wright et al. 2008). We, however, contribute to the entrepreneurial literature by establishing the links between established expertise, strategic choices, and long-term success. Firms initiated by science entrepreneurs with access to both external finance and industry-related knowledge have the greatest propensity to grow in a situation where the team is able to handle the conflicts between entrepreneurs with different mindsets. Firms founded by technology entrepreneurs who make best use of internal resources available throughout the entrepreneurial process have the greatest propensity to survive for a period of at least 10 years. Firms established by habitual entrepreneurs who are best able to discover new opportunities are likely to employ an exit plan to recoup the capital invested in the business when this is worth more than the cost of continued involvement.

\section{Policy Implications}

Our longitudinal evidence has demonstrated that the development path and relatively longterm growth of firms vary according to the specific expertise and knowledge of entrepreneurs. The implication, for practitioners, investors, and policymakers involved in the technological entrepreneurial process, is the value of specific types of expertise possessed by founding entrepreneurs, resources including those available internally and supplied externally through networks, and emerging strategic business choices. Policy schemes (i.e., the Innovation Funds for Small Technology-based Firms and the Torch Programme) designed by the state to provide support to high-tech firms should be tailored to satisfy different needs according to the type of entrepreneur and could offer more resources to firms that have been established by technology and science entrepreneurs. Specifically, scientific entrepreneurs who have an understanding of how to make a new technology sell in the market are fundamental to the establishment of a high-tech SME in the market (Colombo et al. 2009). Support provided by policy schemes to firms initiated by scientific entrepreneurs should focus on helping to build a bridge bringing potential suppliers providing finance and the industry-related knowledge to serve these firms (Rasmussen et al. 2011). A mixture of technology knowledge and industrial-related experience is the most valuable asset required to start a high-tech business with a small amount of investment capital (Liu et al. 2010; Wright et al. 2008). Support focusing on shifting from the initial offer of differentiated products/services to subsequently providing mixed differentiated and standardized products is considered to be essential to growing firms founded by technology entrepreneurs. The importance of access to external finance seems less acknowledged by these firms. Support needed by habitual entrepreneurs who would like to grow an entrepreneurial start-up into a nationally and internationally reputable high-tech business could be provided by a series of training programmes, tackling their weaknesses (such as their lack of work experience in dealing with situations where there are differences in mindset between entrepreneurial team members). 


\section{Theoretical Implication and Future Research}

This work contributes to technological entrepreneurship and human capital theory by developing a conceptual framework drawing on ideas from resource-based theory to examine the relationship between human capital, strategic choice, and formation and survival of hightech SMEs. It demonstrates how a resourcesubstituted approach helps study the business development paths of young high-tech SMEs in China which are typically resource-constrained. The theoretical implication for future research is the need to explore a wider range of strategic business choices (e.g., marketing strategy) and the links with the expertise possessed by founding entrepreneurs and the possibility for resource substitution. Moreover, future research could also examine how social capital substitutes for human capital and financial capital, and how it affects the resource-based business development paths. This study has investigated hightech SMEs in the Chinese context where the business environment for starting a firm operating in a technological industrial sector has yet to catch up with that in Western countries. Nevertheless, a resource-substitution approach and the link between types of entrepreneurs, sources of finance available, strategic choice, and the development path may also be relevant in other contexts such as in the West since most start-up firms typically face resource constraints. A business strategy framework focusing on the probability of resource-substitution and use of external resources in the EIT and bio-tech industrial sectors could be useful in the study of SME operating in all high-tech industrial sectors.

\section{Conclusion}

In conclusion, employing a business strategy approach allowed this work to gain insight into a complex, self-motivated, and resource-based development path that is inadequately understood. Our longitudinal evidence spanning a decade enabled our study to develop theory focusing on nuanced changes to the strategic choices available to a firm and the effects on the business development path of these changes over time. This work provides an improved understanding of the links between the specific expertise held by entrepreneurs and the development path of firms. It suggests that further research is needed to continue the advancement of our knowledge of the mediating role played by intra-strategic choices and human capital characteristics and how it influences the growth and performance of firms.

\section{References}

Arenius, P., and D. De Clercq (2005). "A Network-Based Approach to Opportunity Identification," Small Business Economics 24(3), 249-265.

Audretsch, D. B., and M. Keibach (2004). "Does Entrepreneurship Capital Matter?," Entrepreneurship Theory and Practice 28(5), 419-429.

Barczak, G. (1995). "New Product Strategy, Structure, Process, and Performance in the Telecommunications Industry," Journal of Product Innovation Management 12(3), 224-234.

Barney, J. (1991). "Firm Resources and Sustained Competitive Advantage," Journal of Management 17(1), 99-120.

___ (2001). "Resource-Based Theories of Competitive Advantage: A Ten-Year Retrospective on the Resource-Based View," Journal of Management 27(6), 643-650.

Barton, S. L., and C. H. Matthews (1989). "Small Firm Financing: Implication From a Strategic Management Perspective," Journal of Small Business Management 27(1), $1-7$.

Bates, T. (1990). "Entrepreneur Human Capital Inputs and Small Business Longevity," Review of Economics and Statistics 72(4), 551-559.

Batjargal, B. (2007). "Internet Entrepreneurship: Social Capital, Human Capital, and Performance of Internet Ventures in China," Research Policy 36(5), 605-618.

- (2010). "The Effects of Network's Structural Holes: Polycentric Institutions, Product Portfolio, and New Venture Growth in China and Russia," Strategic Entrepreneurship Journal 4(2), 146-163.

Birley, S., and D. Norburn (1987). "Owners and Managers: The Venture 100 vs the Fortune 500," Journal of Business Venturing 2(4), 351-363.

Chandler, G., and S. Hanks (1993). "Measuring the Performance of Emerging Businesses: A Validation Study," Journal of Business Venturing 8(5), 391-408.

(1998). "An Examination of the Substitutability of Founder's Human and Financial Capital in Emerging Business Ventures," 
Journal of Business Venturing 13(5), 353-369.

Chandler, G., and E. Jensen (1992). "The Founder's Self-Assessed Competence and Venture Performance," Journal of Business Venturing 7(3), 223-236.

Clarysse, B., J. Bruneel, and M. Wright (2011). "Explaining Growth Path of Young Technology-Based Firms: Structuring Resource Portfolios in Different Competitive Environments," Strategic Entrepreneurship Journal 5(2), 137-157.

Colombo, M. G., and L. Grilli (2010). "On Growth Drivers of High-Tech Start-Ups: Exploring the Role of Founders' Human Capital and Venture Capital," Journal of Business Venturing 26(6), 610-626.

Colombo, M. G., L. Grilli, S. Murtinu, L. Piscitello, and E. Piva (2009). "Effects of International R\&D Alliances on Performance Of High-Tech Start-Ups: A Longitudinal Analysis," Strategic Entrepreneurship Journal 3(4), 346-368.

Cooper, A. C. (1981). "Strategic Management: New Ventures and Small Business," Long Range Planning 14(5), 39-45.

(1993). "Challenges in Predicting New

Firm Performance," Journal of Business Venturing 8(3), 241-253.

Cooper, A. C., and A. V. Bruno (1997). "Success Among High-Technology Firms," Business Horizons 20(2), 16-22.

Cooper, A. C., F. Gimeno-Gascon, and C. Woo (1994). "Initial Capital and Financial Capital as Predictors of New Venture Performance," Journal of Business Venturing 9(2), 371395.

Cressy, R. (2006). "Why Do Most Firms Die Young?," Small Business Economics 26(2), 103-116.

Davidsson, P., and B. Honig (2003). "The Role of Social And Human Capital Among Nascent Entrepreneurs," Journal of Business Venturing 18(3), 301-331.

De Clercq, D., and P. Arenius (2006). "The Role of Knowledge in Business Start-Up Activity," International Small Business Journal 24(4), 339-358.

Delmar, F., P. Davidsson, and W. Gartner (2003). "Arriving at the high-Growth Firm," Journal of Business Venturing 18(2), 189216.

Dyer, J. H., H. B. Gregersen, and C. Christensen (2008). "Entrepreneur Behaviours, Opportunity Recognition, and the
Origins Of Innovation Ventures," Strategic Entrepreneurship Journal 2(4), 317-338.

Gartner, W. B. (1988). "Who Is an Entrepreneur?' Is the Wrong Question," American Journal of Small Business 12(4), 11-32.

Gimmon, E., and L. Levie (2010). "Founder's Human Capital, External Investment, and the Survival of New High-Technology Ventures," Research Policy 39, 1214-1226.

Hanks, S. H., C. J. Watson, E. Jansen, and G. N. Chandler (1993). "Tightening the LifeCycle Construct: A Taxonomic Study of Growth Stage Configurations in High Technology Organizations," Entrepreneurship Theory and Practice 18(2), 5-29.

Hitt, M. A., L. Bierman, K. Uhlenbruck, and K. Shimizu (2006). "The Importance of Resources in the Internationalisation of Professional Service Firms: The Good, the Bad, and the Ugly," Academy of Management 49(6), 1137-1157.

Honig, B. (1998). "What Determines Success? Examining the Human, Financial and Social Capital of Jamaican Microentrepreneurs," Journal of Business Venturing 13(3), 371394.

Jack, S. L. (2005). "The Role, Use and Activation of Strong and Weak Ties: A Qualitative Analysis," Journal of Management Studies 42(6), 1233-1259.

Knockaert, M., and D. Ucbasaran (2013). "The Service Role of Outside Boards in HighTech Start-Ups, a Resource Dependency Perspective," British Journal of Management 24(1), 69-84.

Liefner, I., S. Hennemann, and L. Xin (2006). "Cooperation in the Innovation Process in Developing Countries: Empirical Evidence from Zhongguancun, Beijing," Environment and Planning $A$ 38(1), 111-130.

Liu, X., M. Wright, I. Filatotchev, O. Dai, and J. Lu (2010). "Human Mobility and International Knowledge Spillovers: Evidence from High-Tech Small and Medium Enterprises in an Emerging Market," Strategic Entrepreneurship Journal 4(4), 340-355.

Lu, J., and Z. Tao (2010). "Determinants of Entrepreneurial Activities in China," Journal of Business Venturing 25(3), 261-273.

Messersmith, J. G., and W. J. Wales (2013). "Entrepreneurial Orientation and Performance in Young Firms: The Role of Human Resource Management," International Small Business Journal 31(2), 115-136. 
Mosey, S., and M. Wright (2007). "From Human Capital to Social Capital: A Longitudinal Study of Technology-Based Academic Entrepreneurs," Entrepreneurship Theory and Practice 31(6), 909-935.

Neck, H. M., G. D. Meyer, B. Cohen, and A. G. Corbett (2004). "An Entrepreneurial System View of New Venture Creation," Journal of Small Business Management 42, 190-208.

North, D., and D. Smallbone (2000). "The Innovativeness and Growth of Rural SMEs During the 1990s," Regional Studies 34(2), 145-157.

Norton, E. (1991). "Capital Structure and Small Public Firms," Journal of Business Venturing 6(4), 287-303.

Porter, M. E. (1985). Competitive Advantage. New York: The Free Press.

Rasmussen, E., S. Mosey, and M. Wright (2011). "The Evolution of Entrepreneurial Competencies: A Longitudinal Study of University Spin-Off Venture Emergence," Journal of Management Studies 48(6), 13141345.

Rhoads, K., D. Townsend, and L. Busenitz (2011). "Novel Business Models And Radical Technologies Under Capital Constraints: Complements or Liabilities?," Frontiers of Entrepreneurship Research 31(2), 389-402.

Rosenbusch, N., J. Brinckmann, and A. Bausch (2011). "Is Innovation Always Beneficial? A Meta-Analysis of the Relationship Between Innovation and Performance in SMEs," Journal of Business Venturing 26, 441-457.

Sambasivan, M., M. Abdul, and Y. Yusop (2009). "Impact of Personal Qualities and Management Skills of Entrepreneurs on Venture Performance in Malaysia: Opportunity Recognition Skills as a Meditating Factor," Technovation 29(11), 798-805.

Sandberg, W., and C. Hofer (1987). "Improving New Venture Performance: The Role of Strategy, Industry Structure and the Entrepreneur," Journal of Business Venturing 2(1), 5-28.

Schumpeter, J. A. (1934). The Theory of Economic Development: An Inquiry into Profits, Capital, Credit, Interest, and the Business Cycle. Cambridge, MA: Harvard University Press.

Shane, S., and R. Khurana (2003). "Bringing Individuals Back in: The Effects of Career Experience on New Firm Founding," Industrial \& Corporate Change 12(3), 519-543.
Shrader, R., and D. Siegel (2007). "Accessing the Relationship Between Human Capital and Firm Performance: Evidence from Technology-Based New Ventures," Entrepreneurship: Theory and Practice 31(6), 893908.

Simsek, Z., and C. Heavey (2011). "The Mediating Role of Knowledge-Based Capital for Corporate Entrepreneurship Effects on Performance: A Study Of Small And Medium Firms," Strategic Entrepreneurship Journal 5(1), 81-100.

Storey, D., and B. Tether (1998). "New Technology-Based Firms in the European Union: An Introduction," Research Policy 26(9), 933-946.

Tan, J. (2002). "Impact of Ownership Type on Environment-Strategy Linkage And Performance: Evidence from a Transitional Economy," Journal of Management Studies 39(3), 333-354.

Teece, D. (1986). "Profiting from Technological Innovation: Implication for Integration, Collaboration, Licensing and Public Policy," Research Policy 15(6), 285-305.

Thwaites, A., and P. Wynarczyk (1996). "The Economic Performance of Innovation Small Firms in the South East Region and Elsewhere in the UK," Regional Studies 30(2), 135-149.

Ucbasaran, D., A. Lockett, M. Wright, and P. Westhead (2003). "Entrepreneurial Founder Teams: Factors Associated with Member Entry and Exit," Entrepreneurship: Theory and Practice 28(2), 107-127.

Unger, J. M., A. Rauch, M. Frese, and N. Rosenbusch (2011). "Human Capital and Entrepreneurial Success: A Meta-Analytical Review," Journal of Business Venturing 26(3), 341-358.

Vaessen, P., and D. Keeble (1995). "GrowthOriented SMEs in Unfavourable Regional Environments," Regional Studies 29(6), 489-505.

Vanaelst, I., B. Clarysse, M. Wright, A. Lockett, N. Moray, and R. S'Jegers (2006). "Entrepreneurial Team Development in Academic Spin-Outs: An Examination Of Team Heterogeneity," Entrepreneurship: Theory and Practice 30(2), 249-271.

Veugelers, R., and B. Cassiman (1999). "Make and Buy in Innovation Strategies: Evidence from Belgian Manufacturing Firms," Research Policy 28(1), 63-80. 
Wernerfelt, B. (1984). "A Resource-Based View of the Firm," Strategic Management Journal 5, 171-180.

Westhead, P. (1995). "Survival and Employment Growth Contrasts Between Types of Owner-Managed High-Tech Firms," Entrepreneurship Theory and Practice 20(1), 5-27.

Westhead, P., and M. Wright (1998). "Novice, Portfolio, and Serial Founders in Rural and Urban Areas," Entrepreneurship: Theory and Practice 22(4), 63-100.

Westhead, P., M. Wright, and D. Ucbasaran (2001). "The Internationalization of New and Small Firms: A Resource-Based View," Journal of Business Venturing 16(4), 333-358.

Wright, M., K. Hmieleski, D. Siegel, and M. Ensley (2007). "The Role of Human Capital in Technological Entrepreneurship," Entrepreneurship: Theory and Practice 31(6), 791-806.

Wright, M., X. Liu, T. Buck, and I. Filatotchev (2008). "Returnee Entrepreneurs, Science Park Location Choice and Performance: An Analysis of High-Technology SMEs in
China," Entrepreneurship: Theory and Practice 32(1), 131-155.

Wright, M., K. Robbie, and C. Ennew (1997). "Venture Capitalists and Serial Entrepreneurs," Journal of Business Venturing 12(3), 227-249.

Xiao, L. (2011). "Financing High-Tech SMEs in China: A Three Stage Model of Business Development," Entrepreneurship \& Regional Development 23(3-4), 217-234.

Xiao, L., M. Larson, and D. North (2013). "Influence of Entrepreneurial Teams on the Growth Orientation of Early Stage HighTech SMEs in China," Entrepreneurship and Innovation 14(1), 29-38.

Xiao, L., and B. Ritchie (2009). "Access to Finance for High-Tech SMEs: Regional Difference in China," Environment and Planning C 27(2), 246-262.

Zhang, J., V. Souitaris, P. Soh, and P. Wong (2008). "A Contingent Model of Network Utilisation in Early Financing of Technology Ventures," Entrepreneurship Theory and Practice 32(4), 593-613. 